\title{
IGF-1R Inhibitor PL225B
}

National Cancer Institute

\section{Source}

National Cancer Institute. IGF-1R Inhibitor PL225B. NCI Thesaurus. Code C104746.

An orally bioavailable inhibitor of the insulin-like growth factor 1 receptor (IGF-1R) with potential antineoplastic activity. IGF-1R inhibitor PL225B selectively binds to and inhibits the activities of IGF-1R, which may result in both the inhibition of tumor cell proliferation and the induction of tumor cell apoptosis in IGF-1R-overexpressing tumor cells. IGF-1R, a receptor tyrosine kinase overexpressed in a variety of human cancers, plays a significant role in the stimulation of cellular proliferation, oncogenic transformation, and suppression of apoptosis. 